\title{
Effectiveness of Organic Fertigation and Moringa Leaf Extract Spray as An Alternative to Chemical Fertigation for Improving Yield and Quality of Lettuce under Soilless Condition
}

\author{
Mohssen Elbagory ${ }^{1,2}$ \\ ${ }^{1}$ Department of Biology, Faculty of Science and Arts, King Khalid University, Mohail \\ Assir, KSA \\ ${ }^{2}$ Department of Agricultural Microbiology, Soil, Water and Environment Research \\ Institute, Agricultural Research Center (ARC), Giza, Egypt.
}

\begin{abstract}
$\mathbf{T}$ WO experiments were conducted at Sakha Agricultural Research Station, Bacteriology Lab greenhouse for studying the effect of fertigation with fish extract organic solution as an alternative to mineral nutrient solution as well as foliar spray with moringa leaf extract on morphological, chemical, microbial characteristics and yield of lettuce plant grown under soilless system during winter seasons of 2014 and 2015. In general, the results indicated that fertigation with the fish extract organic nutrient solution increase all the studied characteristics compared to fertigation with the mineral nutrient solution, except for $\mathrm{NO}_{3}$ content which sharply decreased due to organic nutrition treatment which attained 157.52 and $175.24(\mathrm{mg}$ plant $^{-1}$ ) compared to 497.14 and $476.8\left(\mathrm{mg} \mathrm{plant}^{-1}\right)$ for mineral nutrition treatment at 2014 and 2015 seasons, respectively. Similarly, foliar spray with moringa extract with mineral nutrition decreased nitrate content (463.46 and $450.16 \mathrm{mg} \mathrm{plant}^{-1}$ ) lower than mineral nutrition without spray (497.14 and $476.8 \mathrm{mg} \mathrm{plant}^{-1}$ ) at 2014 and 2015 seasons, respectively. Therefore, positive results on vegetative growth, chemical characteristics and yield of lettuce plant grown under soilless system by using of fertigation with fish extract organic solution and foliar spray with moringa leaf extract to decrease the nutritive gap and vegetables nitrate pollution problems as well as partially avoid the problem of irrigation water shortage.
\end{abstract}

Keywords: Organic fertigation, Moringa leaf extract, Soilless condition, Lettuce; Yield.

\section{Introduction}

Lettuce is an important leafy vegetable crop, contains many essential elements and vitamins for human healthy, like calcium, iron as well as vitamin A. In addition lettuce contains low calories, so be suitable for decrease human body weight (Maboke, 2009). Lettuce planted in many seasons and its different varieties tolerate a wide range of environmental condition. In Egypt, about 13567 feddan is grown every year with lettuce (Ministry of Agriculture, Land reclamation, Agricultural statics, second part, 2005).

Soilless farming system became important but urgent for using bare lands and top roofs or rock mountains as agricultural productive places. This system characterized with low water consumption, high growth rate of the plant and increases the productivity per unit area as well as low pollution with nitrate. Soilless agriculture of vegetables began since seventeenth century by Boyle, which try to grow plants in soilless vials, then grown after that perforated plastic pipes passing through it nutrient solution with a closed manner, or grown in alternative soilless media like vermiculite, perlite or peat moss (cooper, 1979).

Fertigation with formulated nutrient solutions is low dangerous in relation to nitrate accumulation in plant tissue, because of the balanced formula of the needed nutrients. Although, a lot of amount of nitrates still estimated under system of fertigation with chemical nutrient formula (Leon et al. 2005). Thus, liquid organic fertilizers must intensively be studied to solve this problem which may be some organic residues like industrial fish residues or cheap small fish for making fish extract or may be used as alternative to chemical nutrient fish extract contains most of the needed elements for plant growth (Staley et al. 2013).

*Corresponding author e-mail: melbagory@yahoo.com DOI: 10.21608/JENVBS.2019.6817.1047

(C) 2017 National Information and Documentation Center (NIDOC) 
Among naturally occurring plant growth enhancers, Moringa oleifera has attained enormous attention because of having cytokinin like zeatin, antioxidants such as ascorbic acid, flavonoid, phenolics, carotenoids, amino acids, macro and micro nutrients in its leaves (Foidl et al. 2001; Yasmeen, 2011). Treatment of many crops with moringa leaf extract promoted seed germination, growth and productivity under normal (Nouman et al. 2012) and stress conditions (Yasmeen et al. 2012, 2013), and can be used as organic biostimulants for vegetables (Abou El - Nour and Ewais, 2017). Fuglie (2000) showed that the leaf extract of M. oleifera accelerated growth of young plants, strengthened plants, improved resistance to pests and diseases, increased leaf duration, increased number of roots, produced more and larger fruits and generally increased yield by 20 and $35 \%$. Several recent investigations aiming to increase both the growth parameters measured as plant height, number of leaves, leaf area, fresh and dry weight, number of tillers, shoot vigor, root length, germination percentage and yield represented as fruit number and dry weight by foliar application of moringa leaf extracts at different rates (Prabhu et al. 2010; Balakumbahan and Rajamani, 2010; Phiri, 2010; Nouman et al. 2011).

Therefore, the present study aimed to investigate the importance of diluted fish extract solution in lettuce nutrition and spray with moringa leaf extract on yield, elements composition and nitrates level in lettuce plants grown under system of soilless condition.

\section{Materials and Methods}

\section{Soilless culture used}

Vermiculite is an inorganic substrate which provided from biofertilizers production unit, Soils, Water and Environment Research Institute,
Sakha Agricultural Research Station, Kafr ElSheikh, Egypt.

\section{Fish extract}

The fish extract was made by weighing 10 $\mathrm{kg}$ of fish residues in $100 \mathrm{~L}$ closed container, about $40 \mathrm{~L}$ of water, $200 \mathrm{ml}$ molasses and $250 \mathrm{~g}$ of compost. Air pump operated for aerating the mixture. The aerobic fermentation process was continued for 20 days and one liter of the liquid was mixed with $20 \mathrm{~L}$ of water for irrigation the lettuce plants. All analysis of the using compost (mixing of rice straw with farmyard manure), and fish extract were found in Table 1.

\section{Moringa leaf extract}

According to Nouman et al. (2012), two hundred grams of fresh mature moringa leaves were collected from mature moringa trees at the biofertilizers production unit, Sakha Agricultural Research Station then washed and stored overnight at freezing temperatures. The extracted was sieved through cheesecloth and diluted 30 times with distilled water. Some chemical constituents of moringa leaf extract was determined by Latif and Mohamed (2016), which contain ( $\mathrm{mg} \mathrm{g}^{-1}$ leaves): Amino acids, 365.4; proline, 35.2; total sugars, 325.8; total phenol, 4.5; total flavonoid, 8.19 and ascorbic acid, 8.10 as well as hormones (mg 100 $\mathrm{g}^{-1}$ ): IAA, 0.62; GA, 6.09 and cytokinin, 2.491.

\section{Nutrient solution}

Composed of different macro and micronutrients as formulated by Tzertzakis and Economakis (2008).

\section{Planting}

In a greenhouse winter seasons of 2014 and 2015, vermiculite media was backing in polyethylene bags, about $1 \mathrm{~kg}$ vermiculite per bag. This media was washed with tap water

TABLE 1. Characteristics of the using compost and fish extract.

\begin{tabular}{|c|c|c|c|c|c|}
\hline \multicolumn{6}{|c|}{ Compost } \\
\hline \multicolumn{2}{|c|}{ pH } & 8.26 & $\mathrm{C} / \mathrm{N}$ ratio & \multicolumn{2}{|c|}{16.53} \\
\hline \multicolumn{2}{|c|}{ EC } & 4.80 & N \% & \multicolumn{2}{|c|}{$1.82+0.14$} \\
\hline \multicolumn{2}{|c|}{ Organic carbon (\%) } & 30.08 & $\mathbf{P} \%$ & \multicolumn{2}{|c|}{$0.79+0.0$} \\
\hline \multicolumn{2}{|c|}{ Bulk density $\left(\mathrm{kg} / \mathrm{m}^{3}\right)$} & 632 & K \% & \multicolumn{2}{|c|}{$1.44+0.39$} \\
\hline \multicolumn{2}{|c|}{ Moisture content } & 32 & Germination \% & \multicolumn{2}{|c|}{$86.8+0.5$} \\
\hline $\mathrm{TCB}$ at $30^{\circ} \mathrm{C}$ & $31 \times 10^{5}$ & $\mathrm{TCB}$ at $50^{\circ} \mathrm{C}$ & $48 \times 10^{3}$ & E. coli & 0.0 \\
\hline TCF at $30^{\circ} \mathrm{C}$ & $33 \times 10^{3}$ & TCF at $50^{\circ} \mathrm{C}$ & $17 \times 10^{2}$ & Salmonella sp. & 0.0 \\
\hline TCA at $30^{\circ} \mathrm{C}$ & $47 \times 10^{3}$ & TCA at $50^{\circ} \mathrm{C}$ & $55 \times 10^{2}$ & Shigella sp. & 0.0 \\
\hline \multicolumn{6}{|c|}{ Fish extract } \\
\hline N (ppm) & 2068.80 & $\mathbf{P}(\mathbf{p p m})$ & 562.0 & K (ppm) & 432.90 \\
\hline
\end{tabular}

TCB: Total content of bacteria; TCF: Total content of fungi; TCA: Total content of actinomycetes . 
several times, then the lettuce plants (Lactuca sativa L. cv. Balady) were transplanted as a one in each bag, after that, plants were irrigated with tap water for three days then irrigation with fish extract solution. The control plants were irrigated with chemical nutrient. Lettuce plants were sprayed twice times with moringa leaf extract at age 30 and 45 days after transplanting. The studied treatments were arranged in a randomized complete block design with four replication as $\mathrm{T}_{1}$ : fertigation with mineral nutrient solution; $\mathrm{T}_{2}$ : fertigation with mineral nutrient solution + foliar spray with moringa leaf extract; $\mathrm{T}_{3}$ : fertigation with fish extract organic solution and $\mathrm{T}_{4}$ : fertigation with fish extract organic solution + foliar spray with moringa leaf extract.

\section{Plant sampling}

Plant samples were collected at maturation (70 days) after planting.

\section{Vegetative parameters}

Plant, leaves and head fresh weight $\left(\mathrm{g} \mathrm{plant}^{-1}\right)$, number of leaves, leaf (height and width $\mathrm{cm}$ ), leaf area $\left(\mathrm{cm}^{2}\right)$, stem height $(\mathrm{cm})$ and (plant, leaves and head dry weight g plant $^{-1}$ ) were estimated.

\section{Total Chlorophyll}

Leaf total chlorophyll content (SPAD unit) values was determined by using protable minolta Chlorophyll Meter (Model SPAD-501).

\section{Plant mineral content}

Nitrogen, phosphorus and potassium content (g plant ${ }^{-1}$ ) were determined according to the methods described by Black et al. (1965). Nitrate in the dry plant samples $\left(\mathrm{mg}\right.$ plant $\left.^{-1}\right)$ was extracted by $2 \%$ acitic acid, determined according to Singh (1988). On the other hand, micronutrients content ( $\left.\mathrm{mg}_{\text {plant }}{ }^{-1}\right), \mathrm{Zn}, \mathrm{Mn}, \mathrm{Fe}$ and $\mathrm{Cu}$ were measured using atomic adsorption spectrophotometer (Perkin Elmer 3300) according to (Cottenie et al. 1982).

\section{Microbial estimation}

It was estimated by counting total count of bacteria, fungi and actinomycetes according to Allen (1959).

\section{Statistical Analysis}

Data collected were subjected to the statistical analysis according to the standard methods recommended by Gomes and Gomes (1984) using the computer program (IRRISTAT).

\section{$\underline{\text { Results }}$}

Data in Table 2, showed fresh weight of lettuce plant $\left(\mathrm{g}\right.$ plant $\left.{ }^{-1}\right)$, leaves fresh weight $\left(\mathrm{g} \mathrm{plant}^{-1}\right)$ and head fresh weight $\left(\mathrm{g} \mathrm{plant}^{-1}\right)$ as affected by fertigation with diluted fish extract as organic alternative as well as foliar spray with moringa extract solution compared to recommended mineral fertigation as nutrient solution with or without moringa extract foliar spray. Data illustrated that fertigation with fish extract solution enhanced lettuce growth compared to mineral nutrient solution treatment at both growth seasons, but the differences were mostly not significant except season one, whereas the increases in plant fresh weight showed significances. Foliar spray with moringa extract solution attaint positive results, but the significant differences were clear for plant fresh weight and leaves fresh weight in case of mineral fertigation, season one only. Data presented in Table 2, indicated that application of organic fertigation (fish extract) mostly gave similar leaves number and height as mineral fertigation treatment. The results of the two seasons had similar trend.

The spray with moringa extract solution did not attain an obvious effect on these parameters, except for leaf height and leaf width of mineral fertigation treatment, at season one only. Organic fertigation interacted with moringa extract spray gave significant increases in leaf width over mineral fertigation without moringa extract spray. They attained 14.7 and 15.67 for organic fertigation with moringa extract spray compared to 12.3 and 13.0 for mineral fertigation without moringa extract spray at season one and season two respectively.

The use of fish extract as natural organic nutrient solution obviously increased total chlorophyll, leaf area and stem height over mineral solution (Table 3). The differences, in most cases, were significant. On the other hand, spray whit moringa extract two times through the growth season enhanced these parameters. The effect was positive in case of mineral nutrition or with fish extracts nutrition. The differences than not sprayed controls, sometimes were significant. However, there were consistent significant increases for organic nutrition with moringa spray over mineral nutation (control) in all studied parameters (Table 3 ). Results showed the response of lettuce plant dry weight to organic nutrition and moringa spray. Data indicated that organic nutrition consistently increased the plant dry weight, leaves dry weight and head dry weight over mineral nutrition treatment (control), and the differences were 
TABLE 2. Effect of fertigation with fish extract solution and foliar spray with moringa extract on fresh weight of plant, leaves and head as well as number of leaves, leaf height and leaf width of lettuce plant growing in soilless conditions during 2014 and 2015 seasons.

\begin{tabular}{|c|c|c|c|c|c|c|}
\hline \multirow{2}{*}{ Treatments } & \multicolumn{2}{|c|}{ Plant F. W. (g plant $\left.{ }^{-1}\right)$} & \multicolumn{2}{|c|}{ Leaves F. W. (g plant $\left.{ }^{-1}\right)$} & \multicolumn{2}{|c|}{ Head F. W. (g plant $\left.{ }^{-1}\right)$} \\
\hline & 2014 & 2015 & 2014 & 2015 & 2014 & 2015 \\
\hline$T_{1}$ & $361.57 \mathrm{~b}$ & $456.70 \mathrm{a}$ & $335.13 b$ & $335.03 \mathrm{a}$ & $21.77 \mathrm{a}$ & $69.75 \mathrm{a}$ \\
\hline$T_{2}$ & $425.97 \mathrm{a}$ & $489.30 \mathrm{a}$ & $386.93 \mathrm{a}$ & $348.93 \mathrm{a}$ & $32.23 \mathrm{a}$ & $70.10 \mathrm{a}$ \\
\hline $\mathbf{T}_{3}$ & $409.83 \mathrm{a}$ & $457.75 \mathrm{a}$ & $373.10 \mathrm{ab}$ & 320.69 a & $29.73 \mathrm{a}$ & $54.54 \mathrm{a}$ \\
\hline $\mathbf{T}_{4}$ & $423.37 \mathrm{a}$ & $482.03 \mathrm{a}$ & $386.67 \mathrm{a}$ & $289.77 \mathrm{a}$ & $29.70 \mathrm{a}$ & $77.41 \mathrm{a}$ \\
\hline LSD at $5 \%$ & 43.69 & ns & 38.28 & ns & ns & ns \\
\hline \multirow{2}{*}{ Treatments } & \multicolumn{2}{|c|}{ Number of leaves plant $^{-1}$} & \multicolumn{2}{|c|}{ Leaf Height (cm) } & \multicolumn{2}{|c|}{ Leaf Width (cm) } \\
\hline & 2014 & 2015 & 2014 & 2015 & 2014 & 2015 \\
\hline$T_{1}$ & $27.7 \mathrm{a}$ & $29.00 \mathrm{a}$ & $35.7 \mathrm{~b}$ & $32.00 \mathrm{a}$ & $12.3 \mathrm{~b}$ & $13.00 \mathrm{~b}$ \\
\hline $\mathbf{T}_{2}$ & $29.3 \mathrm{a}$ & $29.67 \mathrm{a}$ & $40.0 \mathrm{a}$ & $27.00 \mathrm{a}$ & $14.3 \mathrm{a}$ & $14.33 \mathrm{ab}$ \\
\hline $\mathbf{T}_{3}$ & $29.0 \mathrm{a}$ & $30.67 \mathrm{a}$ & $40.3 \mathrm{a}$ & $27.67 \mathrm{a}$ & $13.3 \mathrm{ab}$ & $14.33 \mathrm{ab}$ \\
\hline $\mathbf{T}_{4}$ & $29.3 \mathrm{a}$ & $29.00 \mathrm{a}$ & $41.0 \mathrm{a}$ & $29.67 \mathrm{a}$ & $14.7 \mathrm{a}$ & $15.67 \mathrm{a}$ \\
\hline LSD at $5 \%$ & ns & ns & 3.6 & ns & 13.7 & 1.29 \\
\hline
\end{tabular}

TABLE 3. Effect of fertigation with fish extract solution and foliar spray with moringa extract on the total chlorophyll, leave area and stem height as well as dry weight of plant, leaves and head of lettuce plant growing in soilless conditions during 2014 and 2015 seasons.

\begin{tabular}{|c|c|c|c|c|c|c|}
\hline \multirow{2}{*}{ Treatments } & \multicolumn{2}{|c|}{ Total Chlorophyll (SPAD) } & \multicolumn{2}{|c|}{ Leaf area $\left(\mathrm{cm}^{2}\right)$} & \multicolumn{2}{|c|}{ Stem height (cm) } \\
\hline & 2014 & 2015 & 2014 & 2015 & 2014 & 2015 \\
\hline $\mathbf{T}_{1}$ & $40.19 b$ & $42.29 \mathrm{c}$ & $8.79 \mathrm{~b}$ & $9.32 \mathrm{~b}$ & $18.7 \mathrm{~b}$ & $15.67 \mathrm{~b}$ \\
\hline $\mathbf{T}_{2}$ & $41.303 \mathrm{~b}$ & $43.27 \mathrm{bc}$ & $10.19 \mathrm{a}$ & $12.21 \mathrm{a}$ & $20.7 \mathrm{a}$ & $20.33 \mathrm{ab}$ \\
\hline $\mathbf{T}_{3}$ & $42.43 \mathrm{~b}$ & $43.81 \mathrm{ab}$ & $11.15 \mathrm{a}$ & $12.22 \mathrm{a}$ & $20.7 \mathrm{a}$ & $20.00 \mathrm{ab}$ \\
\hline $\mathbf{T}_{4}$ & $44.97 \mathrm{a}$ & $44.78 \mathrm{a}$ & $11.31 \mathrm{a}$ & $11.29 \mathrm{a}$ & $20.7 \mathrm{a}$ & $24.00 \mathrm{a}$ \\
\hline LSD at $5 \%$ & 2.32 & 1.29 & 1.21 & 1.22 & 1.4 & 4.68 \\
\hline \multirow{2}{*}{ Treatments } & \multicolumn{2}{|c|}{ Plant Dry W. (g plant $\left.{ }^{-1}\right)$} & \multicolumn{2}{|c|}{ Leaves Dry W. (g plant $\left.{ }^{-1}\right)$} & \multicolumn{2}{|c|}{ Head Dry W. $\left(\right.$ g plant $\left.^{-1}\right)$} \\
\hline & 2014 & 2015 & 2014 & 2015 & 2014 & 2015 \\
\hline $\mathbf{T}_{1}$ & $15.98 \mathrm{~b}$ & $15.69 \mathrm{c}$ & $9.57 \mathrm{~b}$ & $9.19 \mathrm{c}$ & $2.99 \mathrm{a}$ & $3.13 \mathrm{a}$ \\
\hline $\mathbf{T}_{2}$ & $18.60 \mathrm{a}$ & $18.71 \mathrm{a}$ & $11.41 \mathrm{a}$ & $11.07 \mathrm{a}$ & $2.82 \mathrm{a}$ & $2.83 \mathrm{~b}$ \\
\hline $\mathbf{T}_{3}$ & $17.60 \mathrm{ab}$ & $17.80 \mathrm{~b}$ & $10.42 \mathrm{ab}$ & $11.12 \mathrm{a}$ & $2.68 \mathrm{ab}$ & $2.62 \mathrm{~b}$ \\
\hline $\mathbf{T}_{4}$ & $16.11 \mathrm{~b}$ & $18.23 \mathrm{ab}$ & $9.67 \mathrm{~b}$ & $10.13 \mathrm{~b}$ & $2.34 \mathrm{~b}$ & $2.67 \mathrm{~b}$ \\
\hline LSD at $5 \%$ & 1.94 & 0.85 & ns & 0.445 & 0.41 & 0.253 \\
\hline
\end{tabular}

In a column means followed by a common letter are not significantly different at $5 \%$ level by DMRT, $\mathrm{T}_{1}$ : Fertigation with mineral nutrient solution; $\mathrm{T}_{2}$ : Fertigation with mineral nutrient solution + foliar spray with moringa leaf extract; $\mathrm{T}_{3}$ : Fertigation with fish extract organic solution and $\mathrm{T}_{4}$ : Fertigation with fish extract organic solution + foliar spray with moringa leaf extract.

Env. Biodiv. Soil Security Vol. 2 (2018) 
frequently significant, moringa extract spray increased these parameters over corresponding not-spray control. The differences mostly were significant in case of mineral nutrition, but mostly had no significance for organic nutrition.

Data of Table 4 represented the effect of organic nutrition and/or moringa extract spray on $\mathrm{N}, \mathrm{P}$ and $\mathrm{K}$ content of lettuce shoot system. The data indicated that there were increases in the shoot content from these minerals due to organic nutrition over mineral nutrition, but the differences mostly were not significant. Otherwise, moringa extract spray cause increases in contents of these minerals of lettuce shoot. The differences that corresponding controls were mostly significant in case of $\mathrm{P}$ and $\mathrm{K}$, while shoot content $\mathrm{N}$ of did not show significance.

Nitrate content of lettuce shoot sharply decreased due to organic nutrition with or without moringa spray (Table 4). Organic nutrition treatment attained 157.52 and $175.24\left(\mathrm{mg} \mathrm{plant}^{-1}\right)$ compared to 497.14 and $476.8\left(\mathrm{mg} \mathrm{plant}^{-1}\right)$ for mineral nutrition treatment at 2014 and 2015 seasons, respectively. The differences were significant. Similarly, spray with moringa extract with mineral nutrition decreased nitrate content (463.46 and 450.16 mg plant $^{-1}$ ) lower than mineral nutrition without spray (497.14 and $476.8 \mathrm{mg}$ plant $^{-1}$ ) at 2014 and 2015 seasons, respectively. The best treatment gave lowest nitrate content in lettuce shoot was organic nutrition with spray with moringa extract which attained 165.69 and 162.42 for the season one and two, respectively.

Data of Fig. 1 showed that organic nutrition with or without moringa extract spray slightly increased microelement contents of lettuce shoot over the corresponding controls, and the differences sometimes were significant. The spray of moringa extract increased these microelement shoot contents, and this increase was clear for Fe content, whereas, mineral nutrition with moringa extract treatment gave 937.57 and 869.45 ppm compared to mineral nutrition only (control) which as gave 838.9 and 816.44 for 2014 and 2015 seasons, respectively. Mostly, the treatment organic nutrition with moringa spray exhibited the highest values for contents of all studied microelement over other treatments and the differences than mineral nutrition without moringa extract (control) were mostly significant.

Bacteria, fungi and actinomycetes log number in the plant rhizosphere were as affected by organic nutrition and/ or moringa extract spray (Fig. 2). The data indicated that the differences in counts of these microorganisms between organic nutrition and minerals nutrition were low and mostly were not significant than spray with moringa extract, which did not show a noticeable effect, and the differences between the sprayed plants and control without spray were mostly not significant.

\section{Discussion}

Organic agricultural area continuously increased. For example, Spain organic agricultural sector vastly increased, reached to one million hectar, this for good quality of organic foods. Organic agriculture depends on recycling of organic wastes (Lampkin, (2001). Organic farming became applied on the system of soilless agriculture, which characterized with low water consumption from the most important solid or liquid organic fertilizers used for soilless farming

TABLE 4. Effect of fertigation with fish emulsion solution and foliar spray with moringa extract on $\mathrm{N}, \mathrm{P}, \mathrm{K}$ and NO3 contents of lettuce plant growing in soilless conditions during 2014 and 2015 seasons.

\begin{tabular}{|c|c|c|c|c|c|c|c|c|}
\hline \multirow{2}{*}{ Treatments } & \multicolumn{2}{|c|}{$\mathbf{N}\left(\mathrm{g}\right.$ plant $\left.^{-1}\right)$} & \multicolumn{2}{|c|}{$\mathbf{P}\left(\right.$ g plant $\left.{ }^{-1}\right)$} & \multicolumn{2}{|c|}{ K (g plant $\left.{ }^{-1}\right)$} & \multicolumn{2}{|c|}{$\mathrm{NO}_{3}\left(\mathrm{mg}\right.$ plant $\left.^{-1}\right)$} \\
\hline & 2014 & 2015 & 2014 & 2015 & 2014 & 2015 & 2014 & 2015 \\
\hline$T_{1}$ & $0.793 \mathrm{~b}$ & $0.83 \mathrm{a}$ & $0.084 \mathrm{~b}$ & $0.079 \mathrm{~b}$ & $0.95 b$ & $0.92 \mathrm{c}$ & $497.14 \mathrm{a}$ & $476.80 \mathrm{a}$ \\
\hline $\mathbf{T}_{2}$ & $0.803 \mathrm{ab}$ & $0.87 \mathrm{a}$ & $0.093 \mathrm{a}$ & $0.088 \mathrm{a}$ & $0.97 \mathrm{~b}$ & $0.96 \mathrm{~b}$ & $463.46 \mathrm{~b}$ & $450.16 b$ \\
\hline $\mathbf{T}_{3}$ & $0.810 \mathrm{ab}$ & $0.82 \mathrm{a}$ & $0.088 \mathrm{ab}$ & $0.082 \mathrm{~b}$ & $0.96 \mathrm{~b}$ & $0.95 \mathrm{~b}$ & $157.52 \mathrm{c}$ & $175.24 \mathrm{c}$ \\
\hline $\mathbf{T}_{4}$ & $0.830 \mathrm{a}$ & $0.86 \mathrm{a}$ & $0.093 \mathrm{a}$ & $0.091 \mathrm{a}$ & $0.98 \mathrm{a}$ & $0.97 \mathrm{a}$ & $165.69 \mathrm{c}$ & $162.42 \mathrm{c}$ \\
\hline LSD at $5 \%$ & $\mathrm{~ns}$ & $\mathrm{~ns}$ & 0.006 & 0.003 & 0.014 & 0.01 & 16.28 & 16.66 \\
\hline
\end{tabular}

In a column means followed by a common letter are not significantly different at $5 \%$ level by DMRT, $\mathrm{T}_{1}$ : Fertigation with mineral nutrient solution; $\mathrm{T}_{2}$ : Fertigation with mineral nutrient solution + foliar spray with moringa leaf extract; $\mathrm{T}_{3}$ : Fertigation with fish extract organic solution and $\mathrm{T}_{4}$ : Fertigation with fish extract organic solution + foliar spray with moringa leaf extract. 
a)

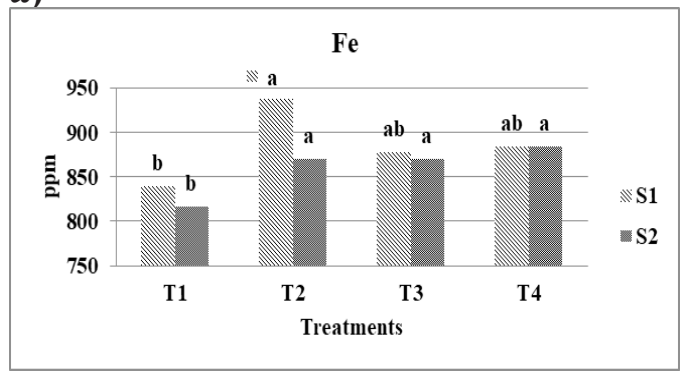

c)

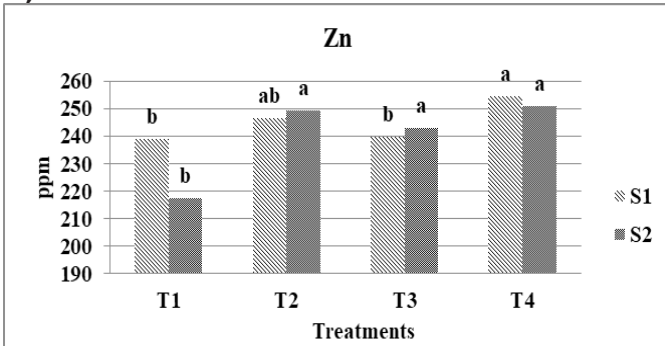

b)

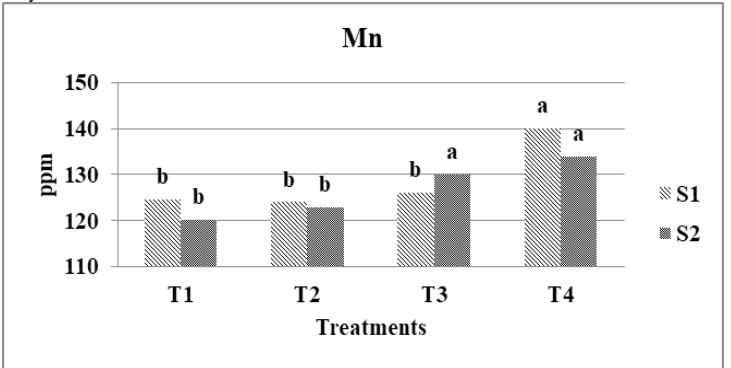

d)

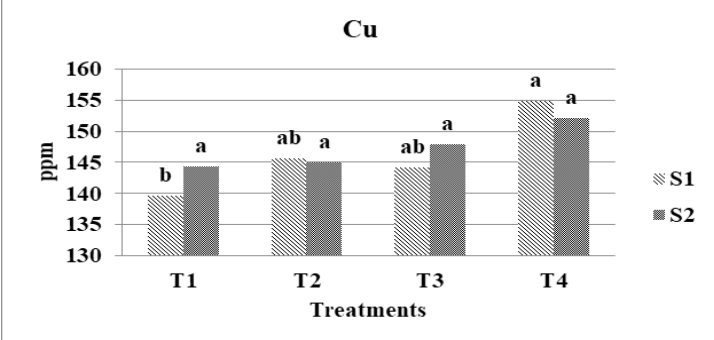

Fig. 1. Effect of fertigation with fish emulsion solution and foliar spray with moringa extract on a) $\mathrm{Fe}$, b) Mn, c) $\mathrm{Zn}$ and d) $\mathrm{Cu}$ content (ppm) of lettuce leaves growing in soilless conditions during 2014 and 2015 seasons. T1: Fertigation with mineral nutrient solution; T2: Fertigation with mineral nutrient solution + foliar spray with moringa leaf extract; $T_{3}$ : Fertigation with fish extract organic solution and $T_{4}$ : Fertigation with fish extract organic solution + foliar spray with moringa leaf extract. S1: First season; S2: Second season. Mean values are significant at $\mathbf{P} \leq \mathbf{0 . 0 5}$.

a)

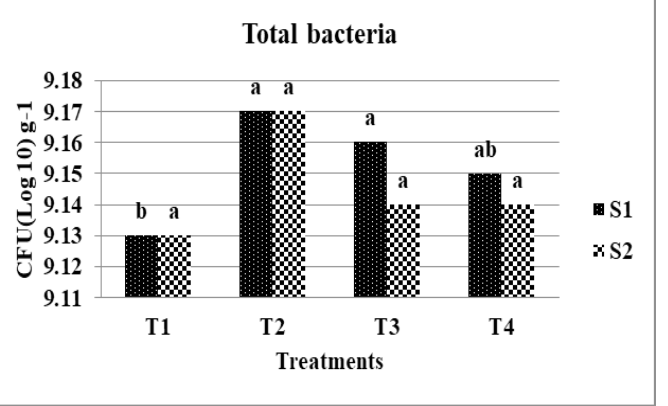

b)

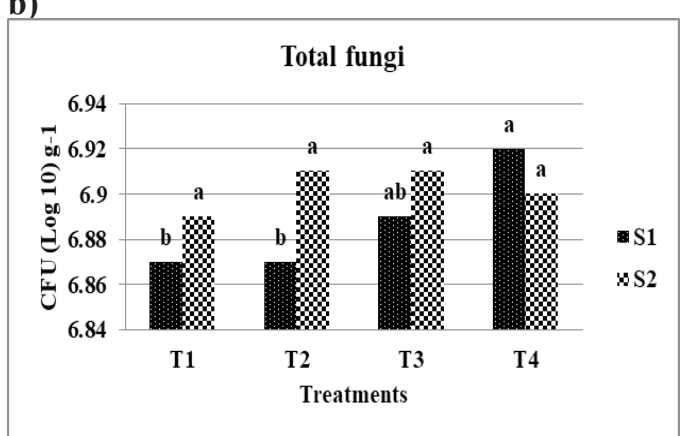

c)

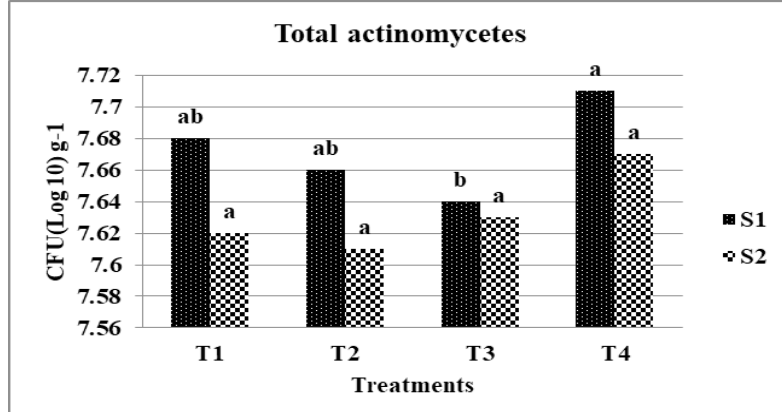

Fig. 2. Effect of fertigation with fish emulsion solution and spray with moringa extract on total counts of a) bacteria, b) fungi and c) actinomycetes of lettuce plant growing in soilless conditions during 2014 and 2015 seasons. $T_{1}$ : Fertigation with mineral nutrient solution; $T_{2}$ : Fertigation with mineral nutrient solution + foliar spray with moringa leaf extract; $T_{3}$ : Fertigation with fish extract organic solution and $T_{4}$ : Fertigation with fish extract organic solution + foliar spray with moringa leaf extract. S1: First season; $\mathrm{S} 2$ : Second season. Mean values are significant at $\mathrm{P} \leq 0.05$. 
is fish residues of food industries, homes and restaurant. (Lopez-Mosquera et al. 2011), found that fish residues contain $10.17 \%$ nitrogen, $1.8 \%$ phosphorus and $0.79 \%$ potassium in addition to high percentage of micro elements. Miles et al. (2009) reported that liquid fish fertilizer N, P and $\mathrm{K}$ about $2.0,4.0$ and $0.2 \%$ respectively, which is the most important liquid organic fertilizer for organic agriculture sector.

Fernandez - Salvador et al. (2015) used a liquid fertilizer from fish residues (fish waste digestion blend) contains $4.0,0.0$ and $1.7 \%$ NPK for fertilization of strawberry, and they mentioned that the fertilizer was adequate to give the plants the needs of nutrient elements except for C and B, the two elements may added with irrigation water.

Also, Zhai (2009) fertilizer organic tomato with compost with a percentage of $50 \%$ of growing media with the adding of liquid feed as plant - based and fish - based organic fertilizer. This fertilizer was adequate but plant - based liquid feed with $50 \%$ compost was the better which gave the highest quality and yield. The results of these investigations agreed with the results of the present study on lettuce yield and elements concentration.

On the other hand, moringa leaves contain many of nutrients and important compound as proteins $(27.2 \%)$, sugars $(38.6 \%)$, Ca $(2 \%), \mathrm{k}$ $(0.013 \%), \mathrm{p}(0.2 \%)$ in addition to reasonable quantities of vitamins like A,B1,B2,B3,C and E. Also, contain hormone like substances as Zeatin (Abdalla, 2013). Fuglie (2000) found that the spray of plants with moringa leaf extracts strengthed their growth, pests and diseases resistance as well as increased number of roots and leaf duration. Also, the fruits yield increased by about $20-35 \%$.

Recently, Abdalla (2013) mentioned that used of 2 and $3 \%$ of moringa leaf extract stimulate biomass production of Eruca plant and stimulate photosynthesis pigments, total sugars, proteins and plant phytohormones levels such as auxin, Gibberellins and Cytokinins. The essential elements (N, P, K, Ca, Mn and Fe) increased also. These results coincided with the results of the present investigation, whereas the spray of lettuce plants with moringa leaf extract increased yield components and quality characteristics as well as essential plant mineral content as N,P,K,Fe,Zn and $\mathrm{Mn}$.
Fortunately, the present study found that spray with moringa leaf extract with the fertilization with fish extract highly significantly decreased nitrates concentrations in lettuce leaves, this results coincided with the results of Treadwell et al. (2011), they found that basil and spearmint plants contain high amount of nitrates in case of chemical fertilization with chemical nutrient solution but, the fertilization with granular poultry manure decreased nitrate leaf concentration at 76 day old.

\section{Conclusion}

We recommend intensifying the researches in point of soilless agriculture system in order to benefit from top roofs and uncultivable bare lands. Positive results on vegetative growth, chemical characteristics and yield of lettuce plant grown under soilless system by using of fertigation with fish extract organic solution and foliar spray with moringa leaf extract.

\section{References}

Abdalla, M.M. (2013) The potential of Moringa oleifera extract as a biostimulant in enhancing the growth, biochemical and hormonal contents in rocket (Eruca vesicaria subsp. Saliva) plants. Inter. J. Physio. Bioch., 5(3): $42-49$.

Abou El - Nour H.H. and Nabila, A. Ewais (2017). Effect of Moringa oleifera leaf extract (MLE) on pepper seed germination seedling improvement, growth, Fruit yield and its quality. Middle East $J$. Agric. Res., 6(2): 448 - 463

Allen (1959). Experiments in Soil Bacteriology. Burgess pub. Co.; Ninn, Minnesota.

Balakumbahan R. and Rajamani K. (2010) Effects of biostimulants on growth and yield of Senna (Cassia angustifolia var KKM1). J. Hort. Sci. Ornam Plants 2(1):16-18.

Black AC, Evans DD, White JL, Ensminyer EL, Clark E.F. (1965). Methods of Soil Analysis. Amer. Soc. Agro. Inc. Mad. Wise U. S. A.

Cooper A. (1979) The ABC of NFT. Grower books, London, $181 \mathrm{pp}$.

Cottenie A. Verloo M. Kiekens L. Velghe G. and Camerlynck R. (1982) Chemical analysis of plants and soils. Laboratory of Analytical and Agrochemistry. State Uni., Ghent:;14-24.

Fernandez - Salvador j. and Stik B.C. (2015). Liquid corn and fish fertilizers are good options for

Env. Biodiv. Soil Security Vol. 2 (2018) 
fertigation in black berry cultivars grown in an organic production system. Hortscience 50 (2): 225 -233 .

Foidl N, Makkar HPS, Becker K (2001).The potential of Moringa oleifera for agricultural and industrial uses.In: Proceedings of the International Workshop" What development potential for Moringa products”, Dar-es-Salaam, Tanzania. pp. 47-67.

Fuglie L.J. (2000). The Miracle Tree: Moringa oleifera: Natural Nutrition for the Tropics. The multiple Attributes of Moringa. p 172.

Gomez K. A. and A.A. Gomez (1984). Statistical Procedures for Agricultural Research $2^{\text {nd }}$ Ed; John Weley and Sons, inc. New York.

Lampkin, N. (2001). Agricultura Ecologica, Mundi prensa, Madrid, Spain.

Latif, H.H. and Mohamed H.I. (2016). Exogenous applications of moringa leaf extract effect on retrotransposon, ultrastructural and biochemical contents of common bean plants under environmental stresses. South Afri. J. Botany 106 221-231

Leon D.F.A., logegaray V. Chiesa A. Desimone M. and Diaz L. (2005). Soilless culture technology for high quality lettuce. ISHS Acta Horticulturae, 697.

Lopez - Mosqueca M.E., Fernandez - Lema E., Villares R., Corral R., Alonso B. and Blanco C. (2011). Composting fish waste and sea weed to produce fertilizer for use in organic agriculture. Procedia Environmental Sciences, 9: 113 - 117.

Maboke M.M. (2009). Effect of plant spacing on growth and yield of lettuce (Lactuca sativa L.) in a soilless production system. S.Afr. J. Plant Soil, 26 (3): 195: 198.

Miles C., Roozen J., Riot A. and Taylor M. (2009). Fertigation Applications and costs in Organic Vegetables. Washington state university, vegetable Research \& Extension, http://vegetables.wsu.edu/.

Nouman W. Siddiqui M.T., Basra S.M.A. (2011). Moringa oleifera leaf extract: An innovative priming tool for rangeland grass. Turk. J. Agric. For. TUBITAK 35:1-11.

Nouman, W., Siddiqui, M.T., Basra, S.M.A. (2012). Moringa oleifera leaf extract: an innovative priming tool for rangeland grasses. Turkish Journal of Agriculture and Forestry 36: 65-75.
Phiri C. (2010). Influence of Moringa oleifera leaf extracts on germination and early seedling development of major cereals. Agric. Biol. J.N Amer. 1(5):774-777.

Prabhu M, Kumar AR, Rajamani K (2010). Influence of different organic substances on growth and herb yield of sacred basil (Ocimum sanctum L) Ind. J. Agric. Res. 44(1): 48-52.

Singh I.P. (1988) A rapid method for determination of nitrate in soil and plant extracts. Plant and Soil, 110: $137-139$

Staley L., Mortley D. G., Bonsi C.K., Bovell Benjamin A. and Gichuhi P. (2013). Hydrolysed organic fish fertilizer and poultry Litter influence total phenolic and antioxidants content but not yield of Arnaranth, Celosia, Gboma and Long bean. Hortscience, 48 (6): $768-772$.

Treadwell D.D., Hochmuth G.J, Hochmuth G. J, Hochmuth R. C., simonne E.H., sargent S. A., Davis L.L., Laughlin W.L. and Berry A. (2011). Hortechnology, 21 (2): 162 - 169.

Tzortzakis N.G. and Economakis C.D. (2008). Impacts of the substrate medium on tomato yield and fruit quality in soilless cultivation. J. Horti. Sci., 35 (2): 83-89.

Yasmeen A. (2011). Exploring the Potential of Moringa (Moringa oleifera) Leaf Extract as Natural Plant Growth Enhancer m.sc. (hons.) Agriculture Department Of Agronomy Faculty of Agriculture, University Of Agriculture, Faisalabad, Pakistan.

Yasmeen A., Basra S.M.A., Farooq M., Rehman H., Hussain N., Athar H.R. (2013). Exogenous application of moringa leaf extract modulates the antioxidant enzyme system to improve wheat performance under saline conditions. Plant Growth Regulation 69, 225-233.

Yasmeen A., Basra S.M.A., Wahid A., Nouman W., Rehman H. (2012). Exploring the potential of moringa (Moringa oleifera) leaf extract (MLE) as seed priming agent in improving wheat performance. Turkish Journal of Botany 37, 512 520 .

Zhai Z., Ehret D.L., forge T., Helmer T. and Dorais W.L.M.(2009). Organic fertilizers for green house tomatoes: productivity and substrate Microbiology. Hortscience, 44 (3): 800 - 809.

(Received 23/12/2018; accepted 10/1/2019) 